\title{
$\mathrm{Au}$ stud 범프의 금속간화합물 성장거동에 미치는 시효처리의 영향
}

\author{
임기태 - 이장희 · 김병준* - 이기욱** - 이민재** . 주영창* - 박영배" \\ 안동대학교 신소재공학부, *서울대학교 재료공학부, **앰코테크놀로지코리아 기술연구소

\section{Effect of Thermal Aging on Intermetallic Compound Growth Kinetics of Au Stud Bump}

\author{
Gi-Tae Lim, Jang-Hee Lee, Byoung-Joon Kim*, Ki-Wook Lee**, Min-Jae Lee**, \\ Young-Chang Joo* and Young-Bae Park ${ }^{\dagger}$ \\ School of Materials Science and Engineering, Andong National University, Andong 760-749, Korea \\ *School of Materials Science and Engineering, Seoul National University, Seoul 151-744, Korea \\ **R\&D Center Amkor Technology Korea Inc., Seoul 133-706, Korea
}

(2007년 11월 21일 접수 : 2008년 1월 2일 채택)

\begin{abstract}
Microstructural evolution and the intermetallic compound (IMC) growth kinetics in an Au stud bump were studied via isothermal aging at 120,150 , and $180^{\circ} \mathrm{C}$ for $300 \mathrm{hrs}$. The $\mathrm{AlAu}_{4}$ phase was observed in an $\mathrm{Al}$ pad/Au stud interface, and its thickness was kept constant during the aging treatment. $\mathrm{AuSn}, \mathrm{AuSn}_{2}$, and $\mathrm{AuSn}_{4}$ phases formed at interface between the Au stud and $\mathrm{Sn}$. AuSn$n_{2}, \mathrm{AuSn}_{2} / \mathrm{AuSn}_{4}$, and $\mathrm{AuSn}$ phases dominantly grew as the aging time increased at $120^{\circ} \mathrm{C}, 150^{\circ} \mathrm{C}$, and $180^{\circ} \mathrm{C}$, respectively, while $(\mathrm{Au}, \mathrm{Cu})_{6} \mathrm{Sn}_{5} /$ $\mathrm{Cu}_{3} \mathrm{Sn}$ phases formed at $\mathrm{Sn} / \mathrm{Cu}$ interface with a negligible growth rate. Kirkendall voids formed at $\mathrm{AlAu} / \mathrm{Au}$, $\mathrm{Au} / \mathrm{Au}-\mathrm{Sn} \mathrm{IMC}$, and $\mathrm{Cu}_{3} \mathrm{Sn} / \mathrm{Cu}$ interfaces and propagated continuously as the time increased. The apparent activation energy for the overall growth of the Au-Sn IMC was estimated to be $1.04 \mathrm{eV}$.
\end{abstract}

Key words intermetallic compound, growth kinetics, Kirkendall void, au stud bump, activation energy.

\section{1. 서 론}

최근 전자기기의 고성능화와 소형화의 추세에 따라 반 도체 소자의 접촉 패드와 패키지 기판을 솔더 범프를 이 용하여 직접 연결함으로써 신호지연의 감소로 인한 고성 능화와 패키지의 면적 감소로 인한 소형화를 이룰 수 있 는 플립칩 패키징 기술이 널리 사용되고 있다. ${ }^{1)}$ 하지만 이러한 플립칩 패키징 기술은 솔더 범프의 본딩을 위해 패드에 금속하부층(under bump metallurgy, UBM)의 형 성이 요구되며 이를 위해서는 고가의 장비와 높은 공정 비용을 필요로 한다. 따라서 기존의 와이어 본딩 기술을 응용한 stud 범프 본딩 기술이 저가의 플립칩 패키징 기 술의 대안으로 주목받고 있다. Stud 범프 본딩 기술은 미 세 피치(pitch)를 적용할 수 있을 뿐만 아니라 UBM 형 성 공정이 불필요하게 되어 공정비용을 줄일 수 있는 장 점이 있다. ${ }^{2}$ Stud 범프 본딩의 재료로는 주로 $\mathrm{Au}$ 가 사 용되고 있으며, 솔더 재료로는 $\mathrm{Pb}$ 에 대한 사용규제로 인 해 $\mathrm{Pb}$ 를 포함하지 않는 무연 솔더가 많이 사용되고 있

Corresponding author

E-Mail : ybpark@andong.ac.kr (Y. B. Park)
는 추세이다. ${ }^{3)}$ 하지만 $\mathrm{Au}$ 의 경우 솔더 내로 빠르게 확 산하여 ${ }^{4-6)}$ 솔더 접합부에 취성이 큰 $\mathrm{Au}-\mathrm{Sn}$ 금속간화합물 (intermetallic compound)을 형성시킨다. 또한 무연 솔더 에서의 높은 $\mathrm{Sn}$ 의 농도 역시 기존에 사용되던 공정조성 의 $\mathrm{SnPb}$ 솔더보다 더 과도한 반응과 금속간화합물의 성 장을 야기한다. ${ }^{3)}$ 이러한 솔더 접합부에서 형성되는 과도 한 금속간화합물은 접합부의 기계적인 신뢰성을 떨어뜨 릴 수 있다. 또한 두 원자의 확산속도의 차이에 의해 계 면에서 생성되는 Kirkendall void 역시 솔더 접합부의 기 계적인 신뢰성을 떨어뜨릴 수 있다. 이와 같이 솔더 접 합부의 신뢰성은 솔더 접합부에서의 솔더 반응과 미세구 조에 민감하다고 알려져 있다. ${ }^{7)}$ 따라서 솔더 접합부의 신 뢰성을 확보하기위해서는 $\mathrm{Au}$ 와 솔더 사이의 계면 미세 구조 변화와 금속간화합물의 형성과 성장 거동에 대한 연 구가 필요하다. 지금까지 박막형태의 $\mathrm{Au}$ 와 솔더 사이에 서의 시효처리에 따른 금속간화합물 형성과 성장거동에 관한 연구는 많이 수행되었지만 Stud 범프 본딩 기술을 이용한 $\mathrm{Au}$ stud 범프 구조에서의 시효처리에 따른 미세 구조 변화와 금속간화합물의 성장거동에 관한 연구는 미 흡한 실정이다.

따라서 본 연구에서는 시효처리에 따른 $\mathrm{Au} s \mathrm{stud} / \mathrm{Sn}$ 범 
프 내의 계면 미세구조 변화와 금속간화합물의 성장거동 에 대한 연구를 수행하였다.

\section{2. 실험 방법}

시효처리에 따른 $\mathrm{Au}$ stud 범프 내의 계면 미세구조 변 화와 금속간화합물의 성장거동을 실시간으로 연구하였다. 본 연구에 사용된 $\mathrm{Au}$ stud 범프 구조를 Fig. 1에 나타 내었다. 상부 칩은 $\mathrm{Si}$ 로 구성되어 있으며 와이어 본딩 (wire bonding) 공정을 통하여 $\mathrm{Al}$ 배선에 $\mathrm{Au}$ stud를 형

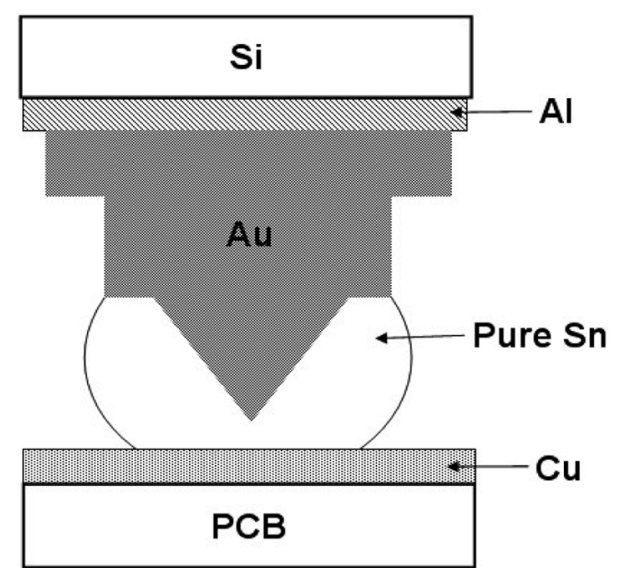

Fig. 1. Schematic diagram of Au stud bump structure.
성하였다. $\mathrm{Au}$ stud가 형성된 상부 칩을 하부 인쇄회로 기판(printed circuit board, $\mathrm{PCB}$ )의 $\mathrm{Cu}$ 배선위에 pure $\mathrm{Sn}$ 솔더를 사용하여 플립칩 본딩 하였다. 리플로우된 3 개의 시편을 \#2000의 연마지와 $1 \sim 3 \mu \mathrm{m}$ 의 연마천을 이 용하여 단면 폴리싱한 후, 일정한 온도로 유지되어 있는 오븐에서 각각 $120,150,180^{\circ} \mathrm{C}$ 의 온도로 300 시간동안 시효처리하면서 지속적으로 관찰하였다. 시효처리에 따른 $\mathrm{Au}$ stud 범프 내 각 계면 미세구조 변화와 금속간화합 물의 성장거동은 주사전자현미경(scanning electron microscopy, $\mathrm{SEM})$ 의 $\mathrm{BSE}$ (back scattered electron)사진과 $\mathrm{EDS}$ (energy dispersive x-ray spectroscopy)를 이용하여 분석 하였다. 또한 금속간화합물의 두께는 image analyzer를 이용하여 측정한 금속간화합물의 면적을 계면의 길이로 나눔으로 써 정의하였고, 시효처리 온도와 시간에 따른 금속간화 합물의 두께변화를 이용하여 활성화 에너지 값을 평가하 는데 적용하였다.

\section{3. 결과 및 고찰}

시효처리 온도와 시간에 따른 $\mathrm{Au}$ stud 범프에서의 계 면 미세구조 변화와 금속간화합물의 성장거동을 관찰하 기위해 각각 $120,150,180^{\circ} \mathrm{C}$ 의 온도에서 260 시간동안 시효 처리한 $\mathrm{Au}$ stud 범프의 전체적인 단면 $\mathrm{BSE}$ 사진 을 Fig. 2에 나타내었다. 그리고 Fig. 3은 Fig. 2에서 측
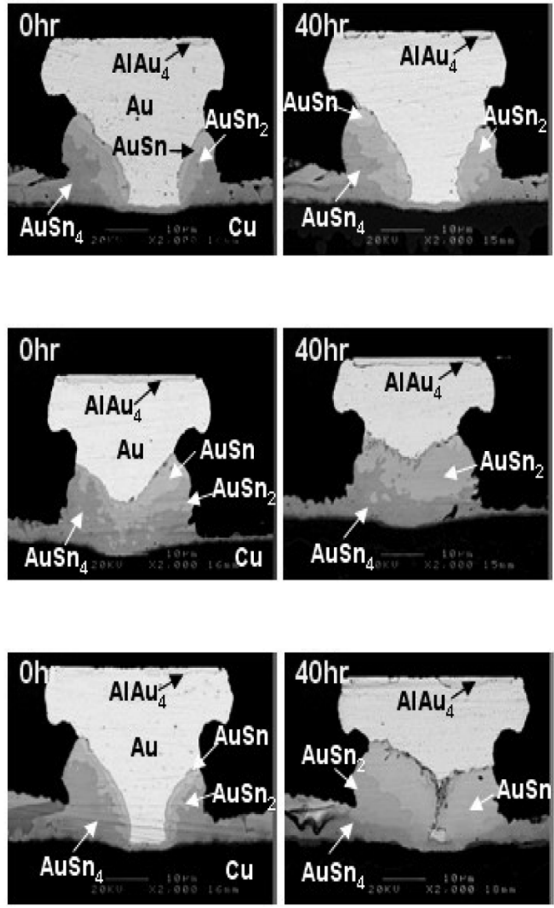

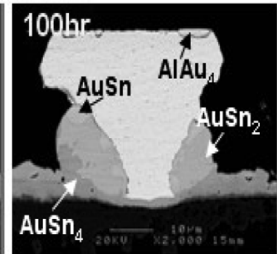

(a)

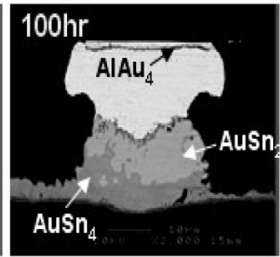

(b)

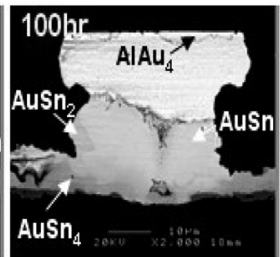

(c)
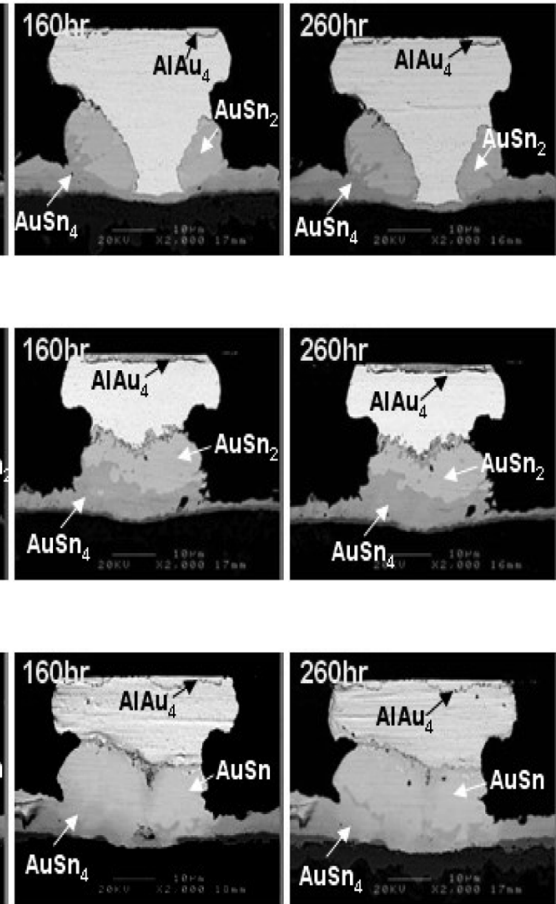

AuSn

Fig. 2. Overall BSE micrographs of the cross-sectioned Au stud bump with aging times at various temperatures; (a) $120^{\circ} \mathrm{C}$, (b) $150^{\circ} \mathrm{C}$, (c) $180^{\circ} \mathrm{C}$. 


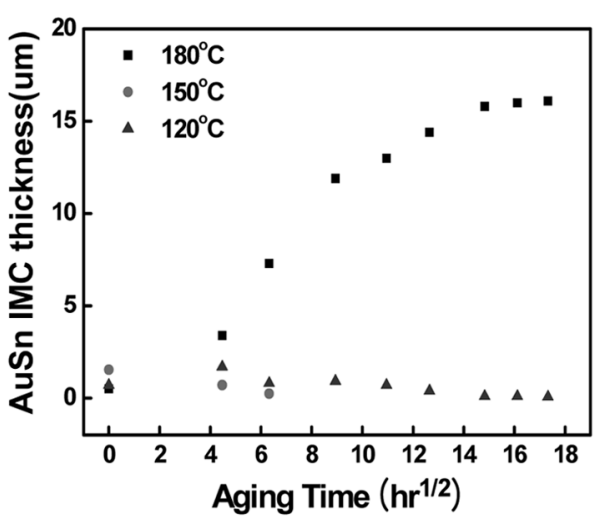

(a)

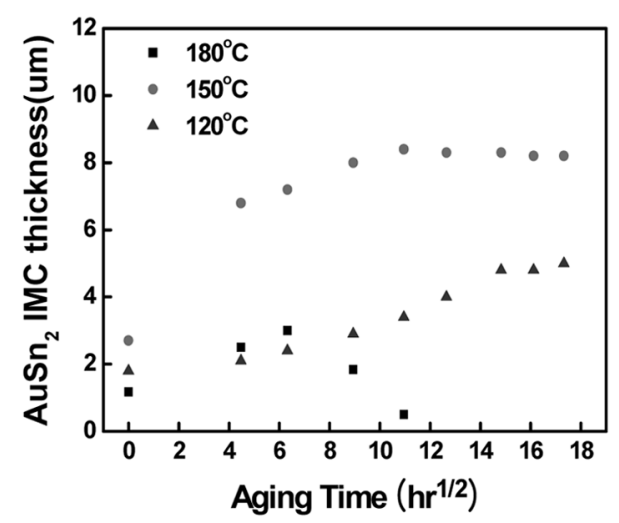

(b)

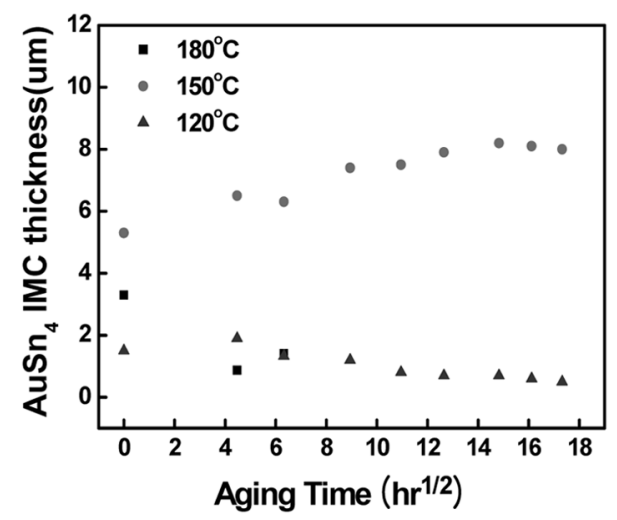

(c)

Fig. 3. Intermetallic compound layer thickness with various aging times and temperatures; (a) AuSn, (b) $\mathrm{AuSn}_{2}$, (c) $\mathrm{AuSn}_{4}$.

정된 $\mathrm{BSE}$ 사진에 대해 image analyzer 분석을 실시하여 $\mathrm{AuSn}, \mathrm{AuSn}_{2}, \mathrm{AuSn}_{4}$ 금속간화합물의 두께를 측정한 후, 시효처리 온도와 시간에 따른 $\mathrm{AuSn}, \mathrm{AuSn}_{2}, \mathrm{AuSn}_{4}$ 금 속간화합물의 두께변화를 나타낸 그래프이다. SEM과 $\mathrm{EDS}$ 분석 결과 세 가지 시편 모두 초기 리플로우 후 이 미 모든 $\mathrm{Sn}$ 이 $\mathrm{Au}$ stud의 $\mathrm{Au}$ 원자와 반응하여 $\mathrm{Au} \mathrm{stud} / \mathrm{Sn}$ 계면으로부터 차례로 $\mathrm{AuSn}, \mathrm{AuSn}_{2}, \mathrm{AuSn}_{4}$ 의 금속간화
합물을 형성하였다. 시효처리 온도와 시간에 따른 두께 변화를 관찰한 결과 시효처리 시간이 경과함에 따라 $120^{\circ} \mathrm{C}$ 에서는 $\mathrm{AuSn}_{2}, 150^{\circ} \mathrm{C}$ 에서는 $\mathrm{AuSn}_{2}$ 와 $\mathrm{AuSn}_{4}$, $180^{\circ} \mathrm{C}$ 에서는 $\mathrm{AuSn}$ 이 지배적으로 성장하였다. $120^{\circ} \mathrm{C}$ 와 $150^{\circ} \mathrm{C}$ 의 경우 초기 리플로우 후의 $\mathrm{Au} s \mathrm{stud}$ 의 형태가 시 효처리 시간이 경과함에 따라 거의 변화가 없었다. 따라 서 시효처리 동안에 $\mathrm{Au}$ stud에서의 $\mathrm{Au}$ 원자가 $\mathrm{Au}-\mathrm{Sn}$ 금 속간화합물 내로 느리게 확산되어 $\mathrm{Au}-\mathrm{Sn}$ 금속간화합물 내의 낮은 $\mathrm{Au}$ 농도로 인해 $\mathrm{AuSn}_{2}$ 와 $\mathrm{AuSn}_{4}$ 가 지배적으 로 성장되었다고 판단된다. 반면 $180^{\circ} \mathrm{C}$ 의 경우에는 시효 처리 시간이 경과함에 따라 $\mathrm{Au}$ stud의 형태가 크게 변 하였다. 따라서 시효처리 동안에 $\mathrm{Au}$ stud에서의 $\mathrm{Au}$ 원 자가 $\mathrm{Au}-\mathrm{Sn}$ 금속간화합물 내로 충분히 확산하여 $\mathrm{Au}-\mathrm{Sn}$ 금속간화합물 내의 높은 $\mathrm{Au}$ 농도로 인하여 $\mathrm{AuSn}$ 이 지 배적으로 성장되었다고 판단되어진다. 하지만 120 과 $150^{\circ} \mathrm{C}$ 의 경우도 충분한 시효처리 시간으로 열에너지의 공 급이 계속된다면 $\mathrm{Au}-\mathrm{Sn}$ 금속간화합물 내의 $\mathrm{Au}$ 농도의 증가로 인해 오랜 시효처리 시간 이후에는 $\mathrm{AuSn}$ 이 지 배적으로 성장되리라 생각된다.

시효처리 시간에 따른 $\mathrm{Al}$ 과 $\mathrm{Au}$ stud 계면에서의 미세 구조 변화와 금속간화합물의 성장거동을 관찰하기위해 리 플로우 후에 $150^{\circ} \mathrm{C}$ 의 온도에서 100 시간동안 시효 처리 한 $\mathrm{Au}$ stud 범프의 $\mathrm{Al} / \mathrm{Au}$ stud 계면 확대 $\mathrm{BSE}$ 사진을 Fig. 4에 나타내었다. 리플로우 후에 $\mathrm{Al} / \mathrm{Au}$ stud 계면에 서는 $\mathrm{AlAu}_{4}$ 가 형성되었고, 시효처리 시간에 따른 $\mathrm{AlAu}_{4}$ 의 두께변화는 관찰되지 않았다. 기 보고에 의하면 $\mathrm{Au}$ 와 $\mathrm{Al}$ 의 확산에서 두 반응 물질의 양이 충분히 공급된 다면 $\mathrm{Al}_{2} \mathrm{Au}_{5}$ 금속간화합물의 성장률이 가장 빠르지만, $\mathrm{Al}$ 의 공급이 충분하지 않을 경우 $\mathrm{Al}$ 이 모두 소모된 후에 는 $\mathrm{AlAu}_{4}$ 가 성장하기 시작한다고 보고되었다. ${ }^{8)}$ 이러한 기 보고를 통하여 본 연구에서 얇은 두께의 $\mathrm{Al}$ 배선이 리 플로우 과정 중에 $\mathrm{Au}$ stud와 반응하여 모두 소모되었기 때문에 $\mathrm{Al}$ 과 $\mathrm{Au}$ stud 계면에서 $\mathrm{AlAu}_{4}$ 만이 관찰되었다 고 판단되어진다. 또한 시효처리 시간이 경과하여도 $\mathrm{AlAu}_{4}$ 의 두께가 일정한 것 역시 리플로우 후에 모든 $\mathrm{Al}$ 이 소모되었기 때문이라 생각된다. Kirkendall void는 시 효처리 시간이 경과함에 따라 $\mathrm{AlAu}_{4}$ 와 $\mathrm{Au}$ stud 계면에 서 관찰되었다.

Figure 5는 시효처리 시간에 따른 $\mathrm{Au}$ stud와 $\mathrm{Sn}$ 계면 에서의 미세구조 변화와 금속간화합물 성장거동을 관찰 하기 위해 리플로우 후에 $150^{\circ} \mathrm{C}$ 의 온도에서 각각 40, 100,300 시간 동안 시효 처리한 $\mathrm{Au}$ stud 범프의 Au stud/ $\mathrm{Sn}$ 계면 확대 $\mathrm{BSE}$ 사진이다. 리플로우 후에 $\mathrm{Au}$ stud로 부터 차례로 $\mathrm{AuSn}, \mathrm{AuSn}_{2}, \mathrm{AuSn}_{4}$ 의 금속간화합물이 생 성되었고, 시효처리 시간이 경과함에 따라 $\mathrm{AuSn}_{2}$ 와 $\mathrm{AuSn}_{4}$ 가 성장하였다. 또한 시효처리 시간이 경과할수록 $\mathrm{Au}$ stud 와 $\mathrm{Au}-\mathrm{Sn}$ 금속간화합물 계면에서 Kirkendall void가 형 


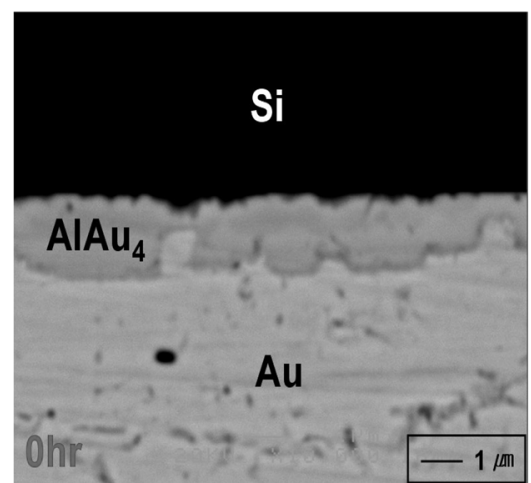

(a)

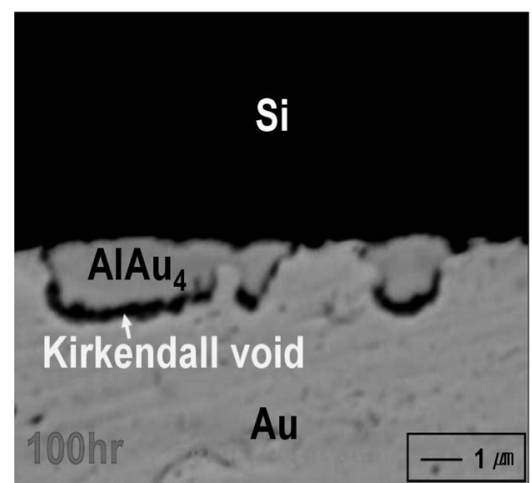

(b)

Fig. 4. Enlarged BSE micrographs of the cross-sectioned $\mathrm{Al} / \mathrm{Au}$ stud interface aged at $120^{\circ} \mathrm{C}$ for $100 \mathrm{hr}$; (a) as-reflowed and (b) $100 \mathrm{hr}$.

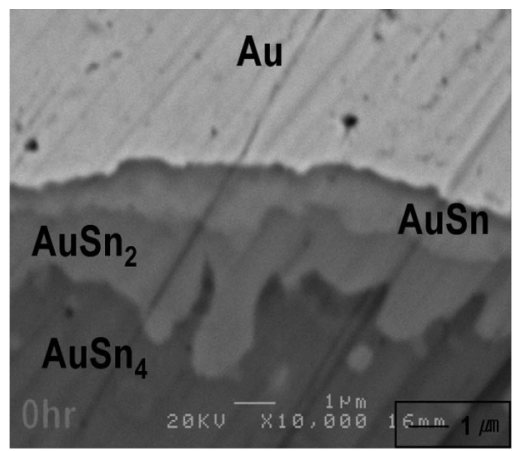

(a)

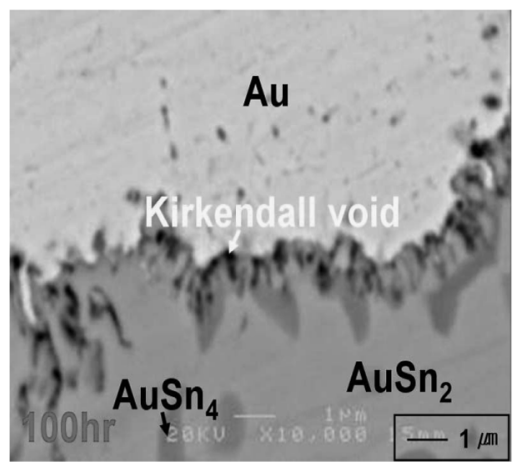

(c)

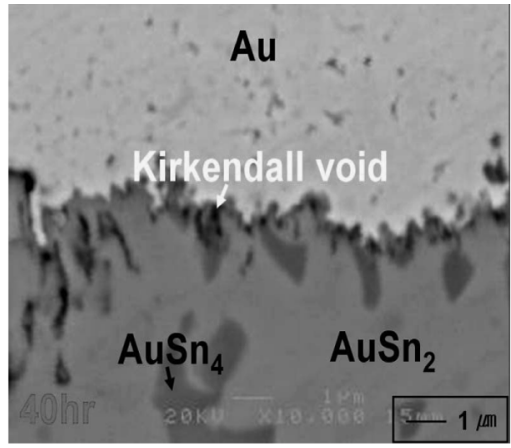

(b)

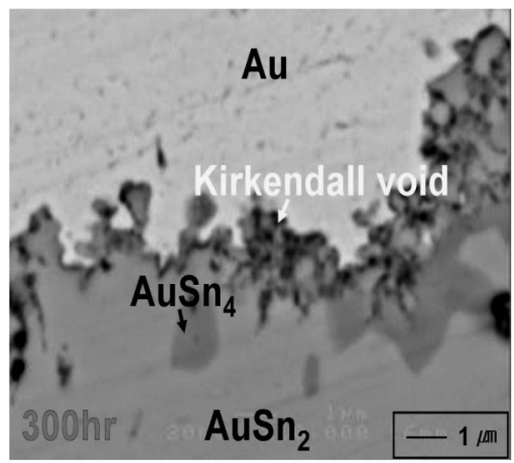

(d)

Fig. 5. Enlarged BSE micrographs of the cross-sectioned $\mathrm{Au}$ stud/Sn interface aged at $150^{\circ} \mathrm{C}$ with various times; (a) as-reflowed, (b) $40 \mathrm{hr}$, (c) $100 \mathrm{hr}$ and (d) $300 \mathrm{hr}$.

성되어 성장하였다.

시효처리 시간에 따른 $\mathrm{Sn}$ 과 $\mathrm{Cu}$ 계면에서의 미세구조 변화와 금속간화합물 성장거동을 관찰하기 위해 리플로 우 후에 $150^{\circ} \mathrm{C}$ 의 온도에서 40 시간 동안 시효 처리한 $\mathrm{Au}$ stud 범프의 $\mathrm{Sn} / \mathrm{Cu}$ 계면 확대 $\mathrm{BSE}$ 사진을 Fig. 6에 나타 내었다. 리플로우 후에 $\mathrm{Sn} / \mathrm{Cu}$ 계면에서는 $(\mathrm{Au}, \mathrm{Cu})_{6} \mathrm{Sn}_{5}$ 와 $\mathrm{Cu}_{3} \mathrm{Sn}$ 이 관찰되었고, 시효처리 시간이 경과함에 따른 두 께변화는 관찰되지 않았다. 일반적으로 $\mathrm{Cu}$ 와 솔더사이의
반응에서는 계면에 $\mathrm{Cu}_{6} \mathrm{Sn}_{5}$ 와 $\mathrm{Cu}_{3} \mathrm{Sn}$ 이 형성된다고 보고 되었다. ${ }^{9-12)}$ 하지만 기 보고와는 달리 $\mathrm{Cu} / \mathrm{Sn}$ 계면에서의 $(\mathrm{Au}, \mathrm{Cu})_{6} \mathrm{Sn}_{5}$ 형성은 리플로우 시 $\mathrm{Au}$ stud에서부터 $\mathrm{Sn}$ 내 로 용해된 $\mathrm{Au}$ 원자가 $\mathrm{Sn}$ 과 $\mathrm{Cu}$ 의 계면 반응에 영향을 미 쳤기 때문이라 판단되어진다. 리플로우 후에 $\mathrm{Cu}_{3} \mathrm{Sn}$ 과 $\mathrm{Cu}$ 의 계면에서는 Kirkendall void가 관찰되었고, 시효처리 시 간이 경과할수록 $\mathrm{Cu}_{3} \mathrm{Sn}$ 과 $\mathrm{Cu}$ 계면을 따라 성장하였다. Figure 7은 시효처리 시간의 제곱근에 따른 각 온도에 


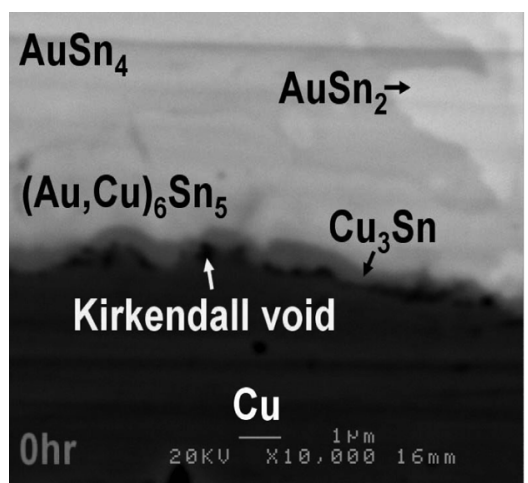

(a)

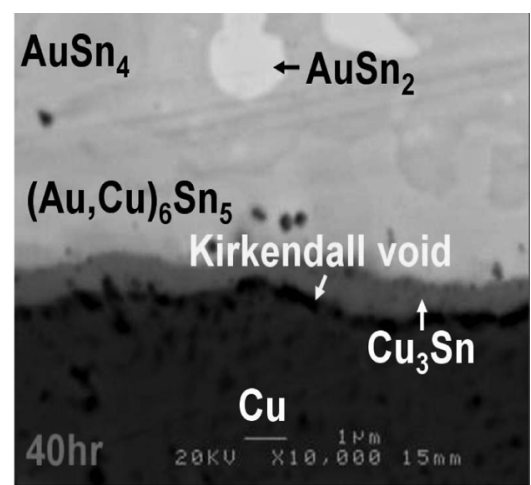

(b)

Fig. 6. Enlarged BSE micrographs of the cross-sectioned $\mathrm{Sn} / \mathrm{Cu}$ interface aged at $150^{\circ} \mathrm{C}$ for $40 \mathrm{hr}$; (a) as-reflowed and (b) $40 \mathrm{hr}$.

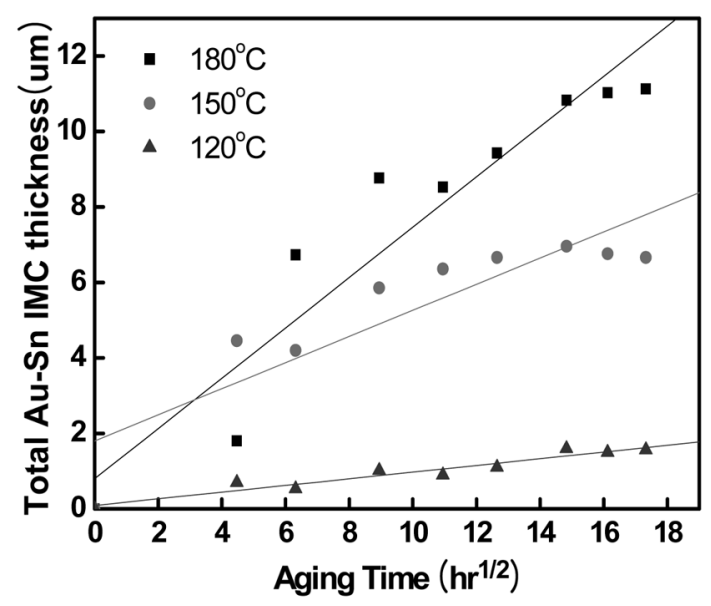

Fig. 7. Total Au-Sn intermetallic compound layer thickness of versus square root of aging time at various aging temperatures.

서의 전체 $\mathrm{Au}-\mathrm{Sn}$ 금속간화합물의 두께를 나타낸 그래프 이다. 시효처리 시간의 제곱근에 따른 전체 금속간화합 물의 두께변화는 $120^{\circ} \mathrm{C}$ 의 경우 직선으로 증가하는 경향 을 보이지만 $150,180^{\circ} \mathrm{C}$ 의 경우는 약간 직선으로 증가 하지 않는 경향을 보인다. 하지만 이는 $\mathrm{Au}$ 의 확산이 $\mathrm{Au}-$ $\mathrm{Sn}$ 금속간화합물의 성장뿐만 아니라 $\mathrm{Au}-\mathrm{Sn}$ 금속간화합 물 내의 상변화에도 영향을 미쳤기 때문이라 생각되어진 다. 따라서 $\mathrm{Au}-\mathrm{Sn}$ 금속간화합물의 성장은 전체적으로 확 산에 의해 지배되었다고 판단되어진다. 또한 시효처리 온 도가 높을수록 전체 $\mathrm{Au}-\mathrm{Sn}$ 금속간화합물의 두께는 더욱 두꺼운 경향을 나타내었다. 전체 Au-Sn 금속간화합물의 성장에 대한 활성화 에너지는 식(1)의 Arrhenius 방정식 을 이용하여 계산할 수 있다.

$$
\mathrm{k}^{2}=\mathrm{k}_{0}^{2} \exp \left(-\frac{\mathrm{E}_{\mathrm{a}}}{\mathrm{RT}}\right)
$$

여기서, $\mathrm{k}^{2}$ 은 반응상수의 제곱 $\left(\mathrm{m}^{2} / \mathrm{s}\right)$ 으로 반응상수 $\mathrm{k}$ 는 Fig. 7의 각 그래프 기울기 값을 나타낸다. $\mathrm{k}_{0}^{2}$ 은 frequency factor, $\mathrm{E}_{\mathrm{a}}$ 는 활성화 에너지, $\mathrm{R}$ 은 기체상수 그리고 $\mathrm{T}$ 는

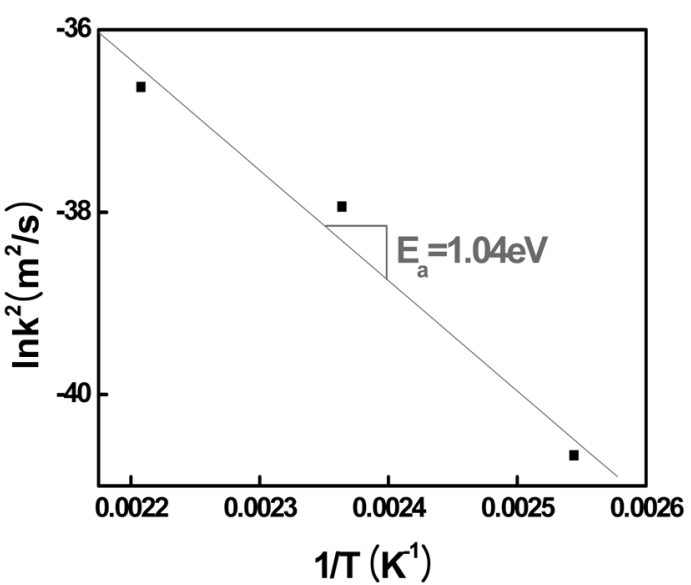

Fig. 8. Arrhenius plot of the total Au-Sn intermetallic compound layer growth.

시효처리 온도를 나타낸다.

전체 $\left(\mathrm{AuSn}+\mathrm{AuSn}_{2}+\mathrm{AuSn}_{4}\right)$ 금속간화합물의 성장에 대 한 활성화 에너지를 구하기 위하여 위의 식(1)을 이용하 여 Arrhenius plot을 하였으며 이를 Fig. 8에 나타내었다. 이와 같은 $\ln \mathrm{k}^{2}-1 / \mathrm{T}$ 그래프의 기울기로부터 구한 전체 $\mathrm{Au}-\mathrm{Sn}$ 금속간화합물의 성장에 대한 활성화 에너지는 1.04 $\mathrm{eV}$ 로 평가되었다.

\section{4. 결 론}

시효처리 온도와 시간에 따른 $\mathrm{Au}$ stud 범프 내의 계 면 미세구조 변화와 금속간화합물 성장거동을 분석하여 다음과 같은 결론을 얻었다.

1. $\mathrm{Au} s t u d / \mathrm{Sn}$ 계면에서는 리플로우 후에 $\mathrm{Au}$ stud로 부터 차례로 $\mathrm{AuSn}, \mathrm{AuSn}_{2}, \mathrm{AuSn}_{4}$ 가 형성되었으며 시효 처리 시간이 경과함에 따라 각각 $120^{\circ} \mathrm{C}$ 에서 $\mathrm{AuSn}_{2}$, $150^{\circ} \mathrm{C}$ 에서 $\mathrm{AuSn}_{2}$ 와 $\mathrm{AuSn}_{4}$ 그리고 $180^{\circ} \mathrm{C}$ 에서는 $\mathrm{AuSn}$ 이 지배적으로 성장하였다. 이를 통해 $\mathrm{Au}-\mathrm{Sn}$ 금속간화합물 성장에 대한 온도 의존성이 존재한다고 판단된다.

2. $\mathrm{Al} / \mathrm{Au}$ stud 계면에서는 리플로우 후에 $\mathrm{AlAu}_{4}$ 가 형 
성되었으며, 시효처리 시간에 따른 $\mathrm{AlAu}_{4}$ 의 두께는 거 의 일정하였다. 이는 높은 온도의 리플로우 과정에서 얇 은 두께의 $\mathrm{Al}$ 배선이 모두 $\mathrm{Au}$ stud와 반응하여 소모되 었기 때문이라 판단된다.

3. $\mathrm{Sn} / \mathrm{Cu}$ 계면에서는 리플로우 후에 $(\mathrm{Au}, \mathrm{Cu})_{6} \mathrm{Sn}_{5}$ 와 $\mathrm{Cu}_{3} \mathrm{Sn}$ 이 형성되었으며 시효처리 시간에 따른 두께변화는 관찰 되지 않았다. 이러한 $(\mathrm{Au}, \mathrm{Cu})_{6} \mathrm{Sn}_{5}$ 의 형성은 리플로우 시 $\mathrm{Au}$ stud에서부터 $\mathrm{Sn}$ 내로 용해된 $\mathrm{Au}$ 원자가 $\mathrm{Cu}$ 와 $\mathrm{Sn}$ 의 계면 반응에 영향을 미쳤기 때문인 것으로 판단된다.

4. Kirkendall void는 $\mathrm{AlAu}_{4} / \mathrm{Au}$ stud, $\mathrm{Au}$ stud/Au-Sn 금속간화합물 그리고 $\mathrm{Cu}_{3} \mathrm{Sn} / \mathrm{Cu}$ 계면에서 형성되었으며 시 효처리 시간이 증가할수록 성장하였다.

5. 시효처리 온도와 시간에 따른 금속간화합물의 두께 변화를 측정한 결과 $\mathrm{Au}-\mathrm{Sn}$ 금속간화합물의 성장은 전체 적으로 확산에 의해 지배되었다고 생각된다. 전체 $\mathrm{Au}-\mathrm{Sn}$ 금속간화합물의 성장에 대한 활성화 에너지는 $1.04 \mathrm{eV}$ 로 평가되었다.

\section{감사의 글}

본 논문은 산업자원부가 지원하는 국가연구개발사업인 “차세대성장동력기술개발사업”을 통해 개발된 결과임을 밝 힙니다.

\section{참 고 문 헌}

1. International Technology Roadmap for Semiconductors 1999 Edition, "Assembly \& Packaging", http://www. itrs.net/Links/2000UpdateFinal/AssemblyPkg2000final.pdf , updated 14 January 2008.

2. M. S. Shin and Y. H. Kim, J. Electron. Mater., 32(12), 1448 (2003).

3. T. K. Lee, S. Zhang, C. C. Wong, A. C. Tan and D. Hadikusuma, Thin Solid Films, 504, 441 (2006).

4. P. G. Kim and K. N. Tu, Mater. Chem. Phys., 53(2), 165171, (1998).

5. T. K. Lee, S. Zhang, C. C. Wong and A. C. Tan, Mater. Sci., Eng. A427, 136 (2006).

6. Y. Tian and C. Wang, Mater. Sci. Eng., B95, 254 (2002).

7. M. Schaefer R, A. Fournelle and J. Liang, J. Electron. Mater., 27, 1167, (1998).

8. E. Imasato, M. Araki, I. Shimizu and Y. Ohno, in Proceedings of Znd Electron. Packag. Technol. conf., 338 (1998).

9. K. N. Tu and R. D. Thompson, Acta metall., 30, 947-952, (1982).

10. Y. C. Chan, A. lex C. K. So and J. K. L. Lai, Mater. Sci. Eng., B55, 5 (1998).

11. C. M. Tsai, W. C. Luo, C. W. Chang, Y. C. Shieh and C. R. Kao, J. Electron. Mater., 33(12), 1424 (2004).

12. J. W. Yoon and S. B. Jung, J. Mater. Sci., 39, 4211, (2004). 